\title{
Linguistic Awareness and English Spelling Difficulties of Iranian EFL Students in Malaysia
}

\author{
MARYAM ALIPOUR \\ Faculty of Social Sciences and Humanities, \\ Universiti Kebangsaan Malaysia, Malaysia \\ mar4ba@yahoo.com \\ KHAZRIYATI SALEHUDDIN \\ Faculty of Social Sciences and Humanities, \\ Universiti Kebangsaan Malaysia, Malaysia \\ SITI HAMIN STAPA \\ Faculty of Social Sciences and Humanities, \\ Universiti Kebangsaan Malaysia, Malaysia
}

\begin{abstract}
The ability to spell properly is usually regarded as a good indicator of one's level of education (Fagerberg, 2006). In this study spelling difficulties are classified as phonological, morphological, and orthographical difficulties in order to examine the correlation between spelling difficulties and the linguistic awareness of Iranian EFL students in Malaysia. The participants of the study were 41 Iranian EFL students (20 males and 21 females) who were selected purposefully from an Iranian secondary school in Kuala Lumpur, Malaysia. A pre-test post-test design adapting a set of tests from Tabrizi et al. (2013) was used to examine the correlation between linguistic awareness and spelling difficulties. Forty words were selected from the second-year English textbook of Iranian EFL students in the pre-test and post-test. Based on the results of the pre-test, the most frequent types of errors were identified. They were related to the Visual Memory, Training Error, Listening Accuracy, Visual Accuracy, Dysgraphia and Visual Sequential Memory. Analysis of the data showed a significant correlation between the participants' linguistic awareness and phonological, morphological and orthographical spelling difficulties. It was concluded that children's developing awareness of linguistic features can help them become more proficient language learners. Findings from this study can assist EFL teachers in mitigating the spelling difficulties among young learners.
\end{abstract}

Keywords: linguistic awareness; spelling; difficulties; EFL

\section{INTRODUCTION}

English language is a global language used in communications, interactions, and information transfer (Pandarangga, S. 2016). In order to be proficient in English language one has to be capable of listening, speaking, reading, and writing in English language. These four skills present unique challenges and difficulties, especially to the FL learners. One of these challenges for FL learners is spelling difficulties. Spelling difficulties are one of the most common type of difficulties among Iranian EFL learners. Linguistic awareness refers to the application of linguistic structures, semantics, phonological, pragmatic, and sociolinguistic knowledge of an individual's first language in the learning of another language (Murphy, 2005). The more an individual is aware of the features of his/her first language, such as its semantics, linguistic structures, sociolinguistic knowledge, phonology, and orthography, the greater opportunity there is for cross-linguistic influence to occur in language learning.

Some research shows that before children begin using syntactic and morphological spelling strategies, they first spell such words phonetically (rolld, kissd) (Nunes et al., 2006). In most European orthographies, the same sound in English language is often spelled in various ways. For example, the phoneme /t/ in the word "list" is spelled as " $d$ ", resulting in "lisd" 
instead of "list" (Nunes et al., 1997; Quirk, 2010; Halliday et al., 2014). However, the exact same phonemes are spelled as 'ed' in the words 'rolled' and 'kissed'. For the inflectional morpheme in regular past verbs, this is its conventional spelling. Such metalinguistic awareness assists greatly in developing spelling and writing proficiency (Sénéchal et al., 2006; Deacon et al., 2009; Bowers et al., 2010; Roncoli and Masterson, 2016). Among the uses of such knowledge is identifying how to spell different sounds when they appear in different parts of the word (Nunes et al., 2006). Some of the main spelling difficulties are phonological, morphological, and orthographical types (Tabrizi, et al., 2013).

Tabrizi et al.'s (2013) book contains a set of approaches and tests which administers creative ways for improving Persian spelling among Iranian students. Mostafa Tabrizi had been investigating the diagnosis of Persian spelling among Iranian students in Tehran since 1991. He started his research with elementary students in Tehran who failed Persian spelling that year. His aim was to provide transitional practices and treatments for spelling instead of using the traditional method. In contrast to Tabrizi's approach, in the traditional approach of teaching spelling, teachers provided information based on lesson instruction without teaching spelling strategies to their students. Also, phonetics was taught formally, and new words were taught in very ineffective ways in each subject. Generally, in the traditional spelling method, the teacher does not give any direct instruction on spelling to students. Students practice the given information of lesson provided by the teacher and then students involve in their own learning. Students' ability to spell words was tested at the end of each Persian lesson without any formal teaching of how to spell.

After 16 years of investigation, Tabrizi proposed several methods within his approach in his book of diagnosis and treatment for Persian dictation in order to overcome the Persian spelling difficulties. Tabrizi et al.'s approach for teaching and learning Persian spelling is recommended by the Ministry of Education of Iran and has been used in Iranian schools since 2007 (Ministry of Education of Iran).

Tabrizi et al.'s approach contains spelling methods designed for teachers to identify the strengths of learning spelling and the areas in spelling that need to be worked on. The book provides creative and new methods of learning how to spell to improve students' performance in spelling Persian words. Tabrizi's et al.'s (2013) approach is significant to Persian speakers as the approach was not only designed for typically developing children but also for children with language disorder.

Based on spelling errors, Tabrizi et al. (2013) categorize their approach into the following methods:

- Visual Memory (14 categories)

- Visual Accuracy (16 categories)

- Listening Accuracy (16 categories)

- Revers Coding (4 categories)

- Mirror Writing (4 categories)

- Training Error (2 categories)

- Dysgraphia (13 categories)

- Visual Sequential Memory (5 categories)

These classifications were built to represent the basic diagnosis of Persian dictation. Each of these classifications provided different methods related to phonology, morphology and orthography of Persian spelling.

According to Tabrizi et al. (2013, p. 31), before selecting the most appropriate methods for students, several steps must be taken into consideration (Figure 1). 


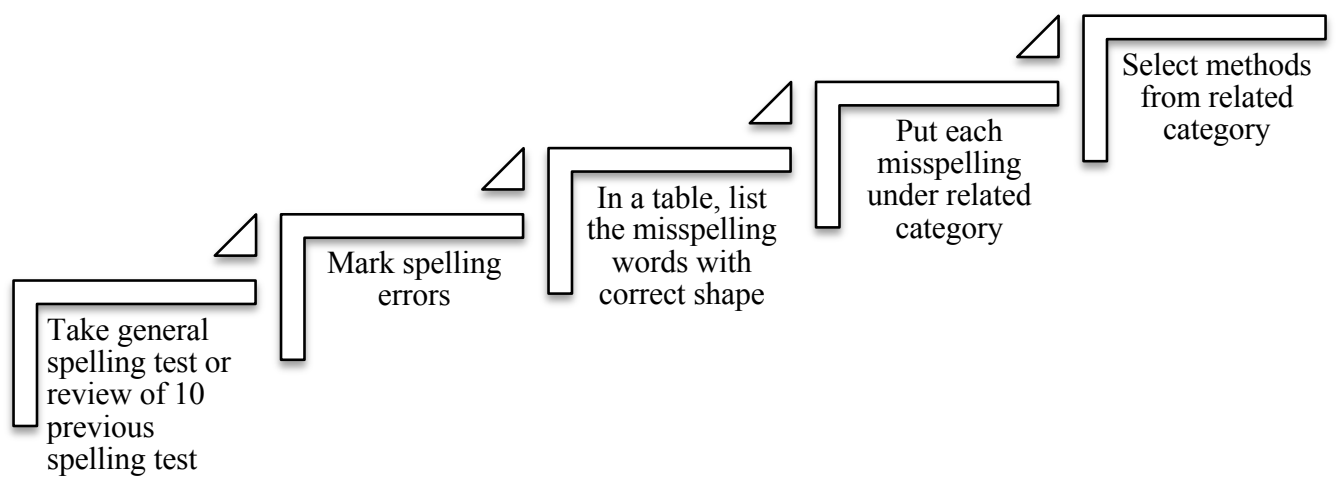

FIGURE 1. Tabrizi et al.'s (2013, P.13) process of selecting spelling methods

\section{MORPHOLOGY}

Morphology is the mental system in word formation. Morphology is related to words, their internal structure, and how they are formed (Aronoff et al., 2011). Morphology is the base for higher order patterns of spelling. Morphological information in complex words can facilitate spelling and that knowledge about the morphemic structure of a language can assist tackling spelling difficulties.

\section{ORTHOGRAPHY}

Orthography refers to the way different spelling patterns and letters are merged to correspond to sounds and create certain words (Khairunnadiah, \& Krish, 2018). Orthography can also be described as the typical spelling system in one language. Hearing a particular speech, the listeners reconstruct and position the different phonetic, phonological, and orthographic symbols that are saved in their mental glossary (Escudero et al., 2014). Orthographic knowledge may contribute to overcome difficulties in spelling. Word representations are established in memory through the linking of a word's spelling with its pronunciation and meaning. Likewise, in order to identify a word precisely, it is necessary to know how letters are combined to form a specific word which may reduce students' spelling difficulties.

\section{PHONOLOGY}

It is the study of how sounds are organized in a language to identify sound organization patterns shared by native speakers of a language (Bird et al., 1995; Senowarsito \& Nur Ardini 2019). Difficulty with phoneme awareness and other phonological skills is a predictor of poor spelling development. Beginning spellers use phonological awareness skills to divide a word into its phonemes as they spell the word.

\section{THE PERSIAN AND ENGLISH LANGUAGE}

According to Souzandehfar (2011), the linguistic and cultural patterns of ESL and EFL learners' original language influence their written English at both the word and discourse levels (Souzandehfar, 2011). Although research on L2 writing has been neglected in many parts of the world including Iran, there is now a greater need to develop a better understanding of this 
(Abdolrezapour et al., 2010), considering the importance of English as a widespread language in international commerce.

Persian, is an Indo-Iranian language that is derived from the Indo-European language family (Ghomeshi, 2003; Trask, 2007; Georgi et al., 2010). It includes dialects spoken in neighboring countries such as Dari in Afghanistan, Tajik in Tajikistan and Farsi in Iran(Windfuhr, 2011; Toosarvandani, 2004). In this study, only the modern written Persian in Iran is discussed. According to Windfuhr (2011), Persian syllables occur at nearly regular intervals. This means that the number of syllables in a sentence determines the amount of time it takes to read it. Persian syllables begin with a consonant (C), followed by a vowel (V). Their possible structures include CV, CVC, or CVCC (see Table 1). As can be observed from these patterns, the Persian language does not have syllable-initial consonant clusters. However, they may be used at the end of the syllables, with a maximum of two consonants in the cluster.

TABLE 1. Persian Syllables Structure

\begin{tabular}{|c|c|}
\hline $\begin{array}{c}\text { Persian } \\
\text { Syllables }\end{array}$ & Examples \\
\hline $\mathrm{CV}$ & $\begin{array}{l}\mathrm{ma} / \mathbf{m p} /[\text { [L] } \\
\text { meaning 'we' }\end{array}$ \\
\hline $\mathrm{CVC}$ & $\begin{array}{l}\text { toop /tup/ [توب] } \\
\text { meaning 'ball' }\end{array}$ \\
\hline CVCC & 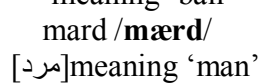 \\
\hline
\end{tabular}

The Persian language contains many Arabic lexical loanwords, but so many of these have been so "Persianized", that their meanings are different from the original Arabic words. The nominal system of Persian morphology is quite simple, as it does not have a case system and is gender-blind. However, there are singular and plural forms. The singular form does not accept suffixes (coda); but the plural form does, e.g., the suffix - $\hat{h} a$ [ه] (which can be used for all nouns that are countable) (QasemiZadeh et al., 2006). For adjectives, the suffixes -tar and tarin are used for comparative and superlative forms, respectively (Karimi et al., 2006). Moreover, the verbal lexemes of the Persian language have a closed word class of approximately 200 elements only. Most verbal meanings in Persian are expressed through verbal predicates formed from a light verbal head and a predicative element. In Persian morphology, there is one verbal stem for past tense forms and another for present tense forms. The former is used for the formation of past tenses, infinitives, the participle of obligation or possibility, as well as the past participle, from which the passive voice and compound tenses are derived from. The latter is used to form present tenses as well as the gerund, present participle and imperative forms. All verbal paradigms in the Persian language are composed of given stems combined with a set of prefixes and suffixes.

The differences between Persian and English are in terms of their rhythm, orthographies, vowels and consonants. Rhythmically, Persian is considered a syllable-timed language, while English is a stress-timed language. Orthographically, the English script is opaque, which means that there is limited one-to-one correspondence between its letters and sounds. Persian, on the other hand, is vowelized. The Persian alphabet also differs completely from the Roman alphabet in terms of the shape of the letters and the direction of reading the alphabet (Baluch, 2005). Furthermore, Persian text can be read without vowels being specified, although only skilled readers are able to do so (Baluch, 1992). However, Persian and English are similar in that their alphabets represent vowels and consonants, whereby words are formed with syllables. Figure 2 illustrates the vowels of the two languages. This comparison is drawn from the work of Yavas and Barlow (2006), with the English vowels encircled by ovals: 

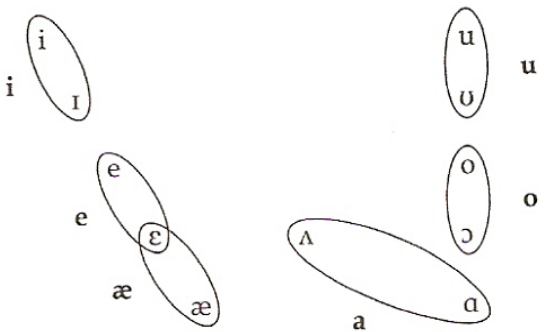

FIGURE 2. Comparison between English and Persian Vowels Source: Yavas et al. (2006, p. 197)

English and Persian sound systems differ considerably in terms of their number of vowels. The English system has more vowels than the Persian system, with the former consisting of 11 (or possibly 12) different vowels, and the latter containing only six vowels. English and Persian also differ in terms of vowel length. In the Persian system, there is no variation in speech, but there is in the English system. To illustrate, consider the two English words live and leave. The meaning changes along with the length of the vowel. Yet another difference can be observed in terms of their tense/lax distinctions. English language has tense/lax vowel pairs such as /e/ vs. / $/ \varepsilon /$, /i/ vs. /I/ and /u/ vs. / $/$. However, such vowel pairings are non-existent in the Persian system. Even though long Persian vowels are sometimes analysed as possessing the same quality as English tense vowels, this assertion is hardly tenable because they are not always as contrastive as English tense/lax vowel pairs (Mirhassani, 2003).

As for the consonantal differences between Persian and English, Yavas et al. (2006) observed that the former has more consonants. Figure 3 shows how the consonants are distributed when the two languages are compared.

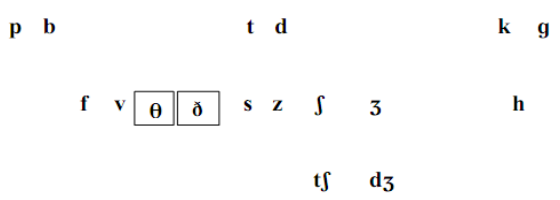

m
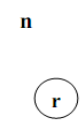

I

FIGURE 3. Overlay of the Persian Consonants on the English Inventory Source: Yavas et al. (2006, p. 197)

More consonants in the Persian language compared to English language means that some consonants that are present in Persian are absent in English, such as the voiced uvular stop $/ \mathrm{y} /$ and the voiceless uvular stop /G/ in the Persian words gham (sadness) and qasr (castle) respectively (Gentry, 1982). Persian is also void of affricates, while fricatives and nasal consonants have a larger distribution in English (Gentry, 1982). Although Persian has a semivowel consonant $/ \mathrm{g} /$, the semivowel does not exactly correspond to the English semivowels $/ \mathrm{v} /$ or $/ \mathrm{w} /$ in vow and why; rather it is a hybrid sound between the two semivowels. In order words, the Persian $/ \mathrm{w} /$ sound does not have an exact point of articulation. This highlights that the difference does not just lie in the number of consonants, but also in the 
distribution patterns of the consonants, which are a more glaring way to distinguish between the two languages (Kalanzadeh et al., 2012).

\section{SPELLING DIFFICULTIES}

Differences in learner background may cause obstacles in the process of learning how to spell. However, The L1 assists learners by serving as a reference to solve problems in the L2 (Brown et al., 2000).

Arab-Moghaddam et al. (2001), exploring the difference between English and Persian spelling, noted that the difficulty Persian students face specifically in learning to spell in English language lies in the irregularity of English language's spelling system (which is also a great difficulty among English L1 speakers), especially when compared to the regularity of the phonetic Persian script to which they have been accustomed. As such, the Persian linguistic background of Iranian EFL learners means that they often search for the correspondence between sounds and symbols in English words (Ediger, 2001); they become confused when they fail to find any. For example, doubled letters as well as silent letters are among the many irregular spelling conventions which are absent in Persian, which results in confusion among Iranian EFL students (Arab-Moghaddam et al.,2001).

Difficulty in English spelling among Persian speakers begins with the Persian writing system, mostly related to orthographically-induced problems. The Persian writing system is cursive in which letters are joined together to form words. For example, the Persian word /pedær/, which means father, is written as يدر which consists of three letters, namely p, d, r. ب. However, it is very unusual to see Persian words being spelled out in the form of separate letters like ب. Furthermore, Persian is written from right to left whereas English is written from left to right. This difference in orientation causes Iranian learners to misspell words, especially those that have letters with mirror shapes such as d, b and p, q (Arab-Moghaddam et al.,2001).

In addition to orthographically-induced problems, Iranian EFL students may also face pronunciation difficulties brought about by the phonological differences between the Persian and English language. Such difficulties hinder accurate spelling in L2 students. For instance, Keshavarz et al. (2002) found that some Iranian EFL students write English words the same way they pronounce them, resulting in words such as esport for sport. This is related to phonological differences because there's no consonant clusters in Persian. This indicates that such spelling errors are phonologically-induced. Hence, such phonological spelling could errors affect the overall writing proficiency of Iranian EFL students (Rahbari, 2019).

Scholars have studied EFL learners from this viewpoint (Leong et al., 2005; Peregoy et al., 2016), and several others, such as the interference of L1 on L2 spelling for different writing systems (Cook, 2010; Verhoeven, 2000), and writing fluency (Chenoweth et al., 2001; Chandler, 2003; Moghaddam, 2011).

One way of investigating the spelling ability of EFL learners is to study the types of spelling errors committed by the learners and the strategies they used to learn how to spell (Baleghizadeh et al., 2011; Kahn-Horwitz et al., 2012; Solati, 2013; Al-zuoud et al., 2013; Goldwater, et al, 2015).). For example, Baleghizadeh et al. (2011) studied the frequency of spelling strategies used by 32 Iranian children aged 7 to 9, who were in their first stages of learning English. The researchers based their identification of strategies on Siegler et al.'s (1991) model of spelling development, which consists of six different spelling strategies: relying on rules, retrieval, visual memory, sounding out, checking and syllabification, and drawing analogies Their findings showed that $70 \%$ of the children spelled out words using not just one strategy, but a combination of them. 
Solati et al. (2011) investigated patterns of spelling errors committed by 32 Persian high school students, and identified that there were five causes of spelling errors: 1) silent letters in the English writing system (e.g./p/ in psychology ); 2) sounds present in the L2 but not in the L1; 3) confusion brought about by words having the same pronunciation but different meanings; 4) sound distinctions present in the L2 but absent in the L1; and (5) letters in English with various pronunciations. Additionally, Solati (2013) examined linguistic deficits through spelling errors committed by EFL learners in Iran. Data was collected from 100 high school students aged from 14 to 16 years old. Results showed that students with poor spelling had problems with the substitution of consonant-clusters, double consonants, vowel digraphs, homophones, silent consonants, silent vowels, and spelling rules.

Review of the literature on Iranian's spelling difficulties shows that despite several studies conducted on Persian, Arabic and Latin languages, there is still a gap between research and practice in addressing Iranian English language learners' spelling difficulties with a focus on phonology, morphology, orthography as well as their linguistic awareness. Therefore, the present study examined linguistic awareness and English spelling difficulties of Iranian EFL students in Malaysia. The differences between Persian and English languages were explained in terms of spelling difficulties and some of the main reasons that contribute to Iranians' spelling difficulties were reviewed. The following section provides a detailed explanation of the research methodology. Addressing Iranian English learners spelling difficulties is important, for example because poor spelling can impede writing and can convey a negative impression even when the content of the writing is excellent. Since in Iran English is only a Foreign Language the students' exposure to real-life use of language (i.e. in the society) is different from those Iranians learning English in Malaysia who can communicate with outsiders, teachers whose native language or mother tongue is not Persian. No study has addressed this issue yet, as most of studies focus on Iranian students leaning English in Iran. This study hopes to fill in this gap to some extent.

\section{METHOD}

Correlation analysis was used to investigate the relationship between three components of spelling difficulties (i.e., phonological, morphological, and orthographical) and linguistic awareness. For the pretest, 40 words were selected from the second-year Iranian EFL text book and were used in the pre-test. The same 40 words were used in the post-test. The justification for using 40 words is that most standardised and criterion-reference measures used 25-50 words to assess students' spelling skills (Apel et al., 2001; Wallace, 2006; Tabrizi et al., 2013). The words were taken from the Second Grade English text book because according to Kibel et al. (1994) and Tabrizi et al. (2013), the words selected for dictation should all be words that learners are familiar with. Feez (2001) and Tabrizi et al. (2013)in this regard says that the selected words for dictation should also match the level of language of the course of study. Therefore, each of the words were selected in line with Tabrizi's approach making a total of 40 words that covered all the approaches. The results of the pre-test were used to identify the most frequent types of spelling difficulties based on Tabrizi et al. (2013). The errors were also analysed in terms of phonological, morphological, and orthographical errors. Below is the list of the 40 words and frequency of errors in the pretest and posttest.

Table 2 shows the descriptive statistics of the phonological, morphological, and orthographical errors. 
TABLE 2. Descriptive Statistics for Linguistic Awareness Variables

\begin{tabular}{lcccc}
\hline Variables & Min & Max & Mean & SD \\
\hline Phonology & 2.00 & 4 & 2.92 & .54 \\
Morphology & 1.83 & 4 & 2.87 & .59 \\
Orthography & 1.80 & 4 & 2.86 & .60 \\
Linguistic Awareness & 1.88 & 4 & 2.88 & .57 \\
\hline
\end{tabular}

Based on these errors, nine methods of teaching spelling from the approach developed by Tabrizi et al. (2013) were regarded as appropriate method to teach students for the errors they committed.

TABLE 3. Descriptive Statistics of Nine Methods Used in Linguistic Awareness

\begin{tabular}{lcccc}
\hline Variables & Min & Max & Mean & SD \\
\hline Flash Card & 2 & 4 & 2.90 & .62 \\
Spell Complement & 2 & 4 & 2.90 & .66 \\
Classification & 1 & 4 & 2.51 & .78 \\
$\begin{array}{l}\text { Word } \\
\text { Improving }\end{array}$ & 1 & 4 & 2.70 & .68 \\
Memory & & & & \\
$\begin{array}{l}\text { Auditory Dictation } \\
\text { Finding Words }\end{array}$ & 1 & 4 & 2.73 & .71 \\
$\begin{array}{l}\text { Adding } \\
\text { Words/Sentences }\end{array}$ & 1 & 4 & 3.02 & .52 \\
Multiple Word & 1 & 4 & 2.85 & .76 \\
$\begin{array}{l}\text { Flash Card } \\
\text { Spell Check }\end{array}$ & 2 & 4 & 3.32 & .65 \\
\hline
\end{tabular}

A set of spelling tests selected from Tabrizi et al. (2013) Book of diagnosis and treatment for Persian dictation/برمان /ختلالات ديكته نويبى was constructed to collect the data.

The first step was to prepare for students a spelling pre-test on words learned from the previous academic years, or notes taken from 10 earlier spelling exams that were tested after each lesson (each passage is considered as a lesson) from students' spelling notebooks. After that, all the misspelled words are listed with correct spelling of the words in a table. Then, each misspelled word is placed under the suggested categories in the same table. Finally, the methods of learning how to spell are selected from the related categories.

In the current study, the pre-test was administered in order to identify the spelling errors from a list of 40 words selected from the students' second-year EFL textbook. Once their performance in the spelling pre-test was analysed, the misspelled words were placed in a table and correct spellings were written next to the words. Then the relation between spelling errors and suggested categories was identified. Once the errors were categorized, the methods to be applied for the present study were identified. Figure 4 is a sample of a pre-test with multiple spelling errors from Participant 7 from female group.

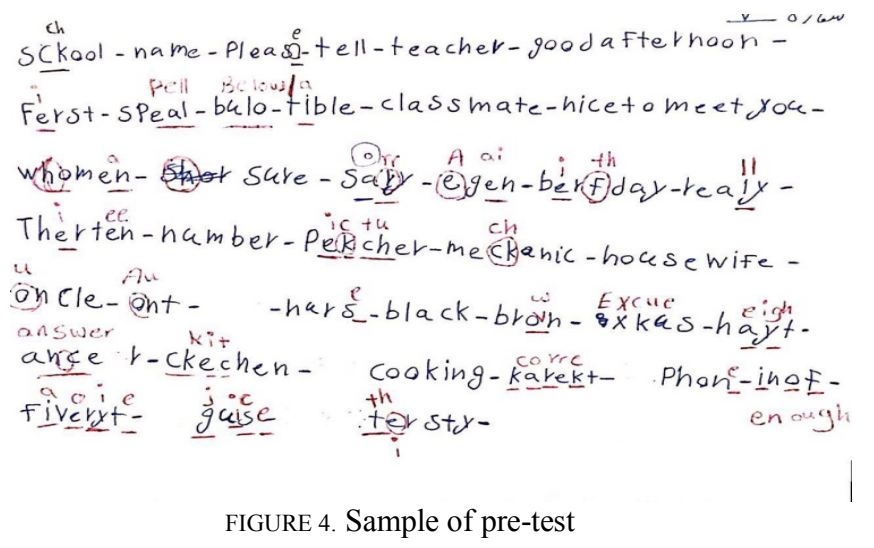


Figure 3 presents a sample of the categorisation of errors from pre-test sample. TABLE 4 is a sample of selecting spelling methods.

TABLE 4. Sample of selecting spelling methods

\begin{tabular}{cccc}
\hline Error & Correct & Error & $\begin{array}{c}\text { Type of } \\
\text { Error }\end{array}$ \\
\hline Sckool & School & $\begin{array}{c}\text { Orthographic } \\
\text { error } \\
\text { ch }\end{array}$ & $\begin{array}{c}\text { Visual } \\
\text { Memory } \\
\text { Visual } \\
\end{array}$ \\
& & & $\begin{array}{c}\text { Accuracy } \\
\text { Training }\end{array}$ \\
& & & Error \\
Pleas & Please & Orthographic & Visual \\
& & error & Memory \\
& & Silent vowel & Training \\
& & error & Error \\
goodafternoon & Good & Incoherent & Dysgraphia \\
& after & writing & \\
& noon & & \\
\hline
\end{tabular}

Based on the analysis the most frequent error types were Visual Memory, Training Error, Listening Accuracy, Visual Accuracy, Dysgraphia and Visual Sequential Memory. None of the participants committed any Reverse Coding and Mirror Writing errors.

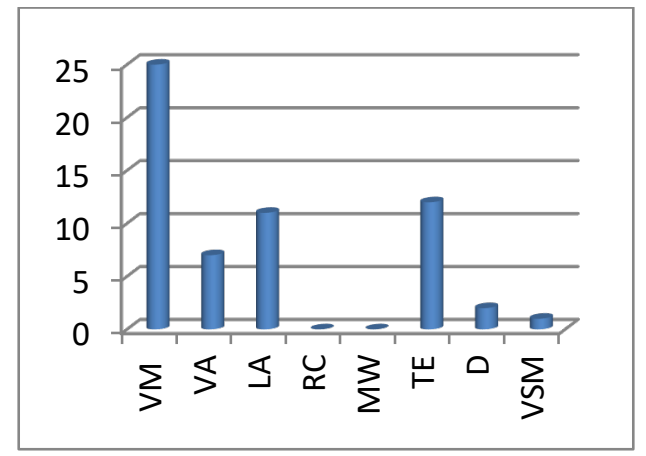

FIGURE 5. The frequency of spelling errors type

The researcher used these nine methods mentioned above. E-Prime 2.0 software was used to collect and analyse the data. The participants received Tabrizi et al. (2013) methods. After using the nine methods to conduct the pretest (the two methods which were not found in the identification stage were excluded), the researcher conducted a posttest, using the same 40 words from the pretest. After the posttest results were analysed, the researcher identified the six most frequently misspelled words.

Although Tabrizi et al.'s approach and the set of methods within their approach are for Persian spelling, the approach was adapted for the teaching of English spelling. This is because Iranian students are familiar with this approach of learning Persian spelling; hence, it is believed that they may be able to transfer a familiar learning approach to a new learning task. However, some modifications have been made to this approach. Rather than using flash cards and whiteboard and markers, the E-Prime 2.0 software, a comprehensive suite of applications for designing test using the computer that records correct and incorrect responses of participants and their reaction times, was used instead in the data collection sessions. E-Prime's ability to record both types of responses is the reason why this software was used instead of the cards and whiteboard and markers in data collection sessions. The data was collected during the sports class and the students' break time because 15 minutes was a short time to 
collect data. Therefore, one and half hour of sports class was given by school every week in order to collect data. After six months of data collection, a post-test was conducted. The words tested were the same 40 words selected from second year English text book, and the given time was the same duration.

\section{DATA ANALYSIS}

The data analysed included descriptive statistics, reliability estimation, correlation analysis, regression analysis. The data for the methods were keyed into the E-Prime. The Statistical Package for the Social Sciences (SPSS) 18.0 was used to analyze the E-prime data results including descriptive statistics, reliability analysis, and correlation analysis. Also, regression analysis was utilized to examine if linguistic awareness has an influence on the English spelling difficulty among Iranian EFL student through analyzing the phonology, morphology, and orthography of English spelling. The correlation coefficient (r) was utilized to determine if there is a relationship between linguistic awareness and English spelling difficulties. T-Test was conducted to examine if there is a significant mean difference between the English spelling difficulties.

\section{RELIABILITY ANALYSIS}

Cronbach's Alpha was used for reliability analysis. Nunnaly (2010) and Hair et al.'s (2010) rule of thumb for measuring Cronbach's Alpha was used, i.e., any amount greater than 0.7 for reliable items. The Alpha for linguistic awareness and English spelling difficulties were measured by Cronbach's Alpha for all tests adapted from Tabrizi (2013).

Reliability of Linguistic Awareness

The Cronbach's Alpha for all nine tests adapted from Tabrizi et al. (2013) was 0.94 for linguistic awareness, 0.92 for phonology, and 0.92 for morphology, and 0.91 for orthography.

TABLE 5. Reliability of Linguistic Awareness

\begin{tabular}{lcccc}
\hline Variables & $\begin{array}{c}\text { Linguistic } \\
\text { awareness }\end{array}$ & phonology & morphology & orthographic \\
\hline $\begin{array}{l}\text { Cronbach } \\
\text { 's Alpha }\end{array}$ & .945 & .921 & .929 & .914 \\
\hline
\end{tabular}

\section{RELIABILITY OF ENGLISH SPELLING DIFFICULTIES}

According to Nunnally's rule of internal consistency, the result of Cronbach's Alpha should be greater than 0.7. Therefore, the pretest and posttest of English spelling difficulties were reliable, 0.85 and 0.82 respectively.

Descriptive Statistics

The participants of this study were 41 EFL students from Iranian secondary schools in Kuala Lumpur. English spelling error tests were conducted as pre-test and post-test.

TABLE 6. The Tests from Linguistic Awareness ( $N=41)$

\begin{tabular}{lcccc}
\hline Variables & $\begin{array}{c}\text { Poor } \\
(\mathbf{\%})\end{array}$ & $\begin{array}{c}\text { Average } \\
\mathbf{( \% )}\end{array}$ & $\begin{array}{c}\text { Good } \\
\mathbf{( \% )}\end{array}$ & $\begin{array}{c}\text { Excellent } \\
\mathbf{( \% )}\end{array}$ \\
\hline Flash Card & 0.00 & 24.40 & 61.00 & 14.60 \\
Spell & 0.00 & 26.80 & 56.10 & 17.10 \\
$\begin{array}{l}\text { Complement } \\
\begin{array}{l}\text { Classification } \\
\text { Word }\end{array}\end{array}$ & 7.30 & 43.90 & 39.00 & 9.80 \\
\hline
\end{tabular}




\begin{tabular}{lcccc}
\hline $\begin{array}{l}\text { Improving } \\
\text { Memory }\end{array}$ & 4.90 & 26.80 & 66.00 & 7.30 \\
$\begin{array}{l}\text { Auditory } \\
\text { Dictation }\end{array}$ & 2.40 & 34.10 & 51.20 & 12.20 \\
$\begin{array}{l}\text { Finding Words } \\
\text { Adding }\end{array}$ & 0.00 & 12.20 & 73.20 & 14.60 \\
$\begin{array}{l}\text { Words/Sentence } \\
\text { Multiple Word }\end{array}$ & 2.40 & 29.30 & 48.80 & 19.50 \\
$\begin{array}{l}\text { Flash Card } \\
\text { Spell Check }\end{array}$ & 0.00 & 9.80 & 48.80 & 41.50 \\
\hline
\end{tabular}

**The number of correct words were Poor $="<5$ "

Average="5", Good="6-7", Excellent="8-10" and Table 8 .

Descriptive statistics of linguistic awareness and variables are presented in Table 7

TABLE 7. Descriptive Statistics of Linguistic Awareness ( $N=41)$

\begin{tabular}{lcc}
\hline Variables & Mean & SD \\
\hline Flash Card & 2.90 & .62 \\
Spell Complement & 2.90 & .66 \\
Classification Word & 2.51 & .78 \\
Improving Memory & 2.70 & .68 \\
Auditory Dictation & 2.73 & .71 \\
Finding Words & 3.02 & .52 \\
Adding Words/Sentences & 2.85 & .76 \\
Multiple Word Flash Card & 2.85 & .73 \\
Spell Check & 3.32 & .65 \\
\hline
\end{tabular}

TABLE 8. Descriptive Statistics for Linguistic Awareness Variables $(\mathrm{N}=41)$

\begin{tabular}{lcc}
\hline Variables & Mean & SD \\
\hline Phonology & 2.92 & .54 \\
Morphology & 2.87 & .59 \\
Orthography & 2.86 & .60 \\
Linguistic Awareness & 2.88 & .57 \\
\hline
\end{tabular}

As for the spelling errors, the participants were asked to answer 40 questions once in pretest and once in posttest.

TABLE 9. Descriptive Statistics for English Spelling Errors ( $\mathrm{N}=41)$

\begin{tabular}{lcc}
\hline Variables & Mean & SD \\
\hline Pre-test & 2.03 & .76 \\
Post-test & 2.76 & .77 \\
\hline
\end{tabular}

The words that were incorrectly spelled in both the pre-test and post-test were identified and presented through descriptive statistics. The following information was obtained of pretest and posttest:

TABLE 10. The Frequency of False Words in Pre-test and Post-test

\begin{tabular}{llll}
\hline No. & \multicolumn{1}{c}{ Words } & Pre-test & Post-test \\
\hline 1 & School & 20 & 4 \\
2 & Name & 2 & 3 \\
3 & Please & 27 & 6 \\
4 & Tell & 21 & 4 \\
5 & Teacher & 15 & 2 \\
6 & Good afternoon & 19 & 4 \\
7 & First & 16 & 5 \\
8 & Spell & 17 & 4 \\
9 & Below & 26 & 4 \\
10 & Table & 19 & 2 \\
11 & Classmate & 15 & 4 \\
12 & Nice to meet you & 21 & 3 \\
\hline
\end{tabular}




\begin{tabular}{|c|c|c|c|}
\hline 13 & Friend & 29 & 9 \\
\hline 14 & Woman & 19 & 11 \\
\hline 15 & Sure & 22 & 13 \\
\hline 16 & Sorry & 23 & 10 \\
\hline 17 & Again & 20 & 5 \\
\hline 18 & Birthday & 25 & 2 \\
\hline 19 & Really & 30 & 6 \\
\hline 20 & Thirteen & 24 & 2 \\
\hline 21 & Number & 22 & 4 \\
\hline 22 & Picture & 25 & 10 \\
\hline 23 & Mechanic & 28 & 22 \\
\hline 24 & Housewife & 24 & 9 \\
\hline 25 & Uncle & 23 & 15 \\
\hline 26 & Aunt & 19 & 21 \\
\hline 27 & Nurse & 20 & 22 \\
\hline 28 & Black & 19 & 10 \\
\hline 29 & Brown & 24 & 9 \\
\hline 30 & Excuse & 30 & 18 \\
\hline 31 & Height & 33 & 17 \\
\hline 32 & Answer & 20 & 16 \\
\hline 33 & Kitchen & 23 & 12 \\
\hline 34 & Cooking & 21 & 17 \\
\hline 35 & Correct & 26 & 13 \\
\hline 36 & Phone & 24 & 17 \\
\hline 37 & Enough & 33 & 15 \\
\hline 38 & Favorite & 34 & 29 \\
\hline 39 & Juice & 36 & 14 \\
\hline 40 & Thirsty & 31 & 27 \\
\hline
\end{tabular}

Some of the items were phrases, e.g. item 6 and item 12. These phrases are equivalent to single words as both indicate a "unit" greeting despite the number of words is more than one. This would not affect the reliability of the test, the results and the analysis as these phrases are taken as single units of meaning, like a word. In other words, even though "good afternoon" consists of two words, it indicates one unit of meaning, i.e. the greeting in the afternoon time. The first six misspelled words in post-test and pre-test were identified and ranked. The purpose of having the most frequently misspelled words was to identify and use them in the following stages in the pretest and posttest stages.

TABLE 11. The Ranking First Six False Words in Pre-test and Post-test

\begin{tabular}{clllc}
\hline Ranks & Pre-test's words & F & Post-test's Word & F \\
\hline 1 & Juice & 36 & Favorite & 29 \\
2 & Favorite & 34 & Thirsty & 27 \\
3 & Enough, Height & 33 & Nurse, Mechanic & 22 \\
4 & Thirsty & 31 & Aunt & 21 \\
5 & Excuse, Really & 30 & Excuse & 18 \\
6 & Friend & 29 & & \\
**F: Frequency of incorrect responses & & &
\end{tabular}

The following section presents the t-test and one way-ANOVA to compare pre-test and post-test.

\section{COMPARING PRETEST AND POSTTEST}

This section provides a comparison of the pre-test and post-test for phonology, morphology, and orthography as well as errors of linguistic awareness using ANOVA test and t-tests. In order to see if there is a relationship, and if this relationship is strong or weak we should report a correlation coefficient along with the $p$ value. ANOVA is used to determine if there is a statistically significant difference among the groups. The differences between pre-test and posttest were investigated across the group $(\mathrm{N}=41)$ through independent sample t-test. The mean for the pre-test score was 1.98 with standard deviation of 0.76 , whereas the mean for the posttest score was 3.10 with standard deviation of 0.66 . In addition, there was a significant 
relationship between pre-test and post-test results $(\mathrm{r}=0.8)$. The results of paired tests showed that the mean difference between the two tests was $\mathrm{M}=-1.12$ with standard deviation of 0.45 . Also, the result for the relationship between pre-test and post-test indicated $t(40)=-15.68$, $\mathrm{p}=.000(<.05)$. Therefore, there was a significant difference between the two tests.

The mean and ANOVA were compared for the pretest and posttest in terms of subscales of linguistic awareness.

TABLE 12. Comparing Variables of Linguistic Awareness

\begin{tabular}{lllll}
\hline & phonology & morphology & orthographic & $\begin{array}{l}\text { Linguistic- } \\
\text { awareness }\end{array}$ \\
\hline Mean & 2.9199 & 2.8659 & 2.8585 & 2.8814 \\
$\mathbf{N}$ & 41 & 41 & 41 & 41 \\
Std. & 0.54497 & 0.59187 & 0.59874 & 0.57413 \\
Deviation & & & & \\
\hline
\end{tabular}

TABLE 13. The ANOVA test- Linguistic Awareness

\begin{tabular}{llll}
\hline & $\begin{array}{l}\text { Sum of } \\
\text { Squares }\end{array}$ & Df & $\begin{array}{l}\text { Mean } \\
\text { Square }\end{array}$ \\
\hline phonology & 23.387 & 72 & 0.325 \\
morphology & 25.019 & 72 & 0.347 \\
orthography & 25.709 & 72 & 0.357 \\
Linguistic & 24.208 & 72 & 0.336 \\
awareness & & & \\
\hline
\end{tabular}

CORRELATION ANALYSIS

The relationships between linguistic awareness and English spelling difficulties were investigated using Pearson Correlation method. The correlation analysis was performed across those variables for participants $(\mathrm{N}=41)$.

TABLE 14. Correlation Analysis

\begin{tabular}{lcc}
\hline & Linguistic Awareness & English Spelling Errors \\
\hline Linguistic Awareness & 1.00 & \\
English Spelling Errors & $.763^{* *}$ & 1.00 \\
\hline ** Correlation is significant at the 0.01 level (2-tailed). &
\end{tabular}

There was a significant correlation between linguistic awareness and English spelling errors $(\mathrm{r}=0.763)$. The significant correlation between the participants' English spelling difficulties and their linguistic awareness indicated that students and teachers' linguistic awareness, such as participation in reflection and expression on the spelling words or activities when teaching and learning spelling has a positive effect on learning spelling.

\section{DISCUSSION/CONCLUSION}

Analysis of the data showed that the most frequent error types were related to the Visual Memory, Training Error, Listening Accuracy, Visual Accuracy, Dysgraphia and Visual Sequential Memory. Participants did not commit any Reverse Coding and Mirror Writing difficulties may imply that for Persian EFL students, learning the direction for writing a letter/word could be faster than learning the general shape of the letter/word As suggested by Tabrizi et al. (2013), one of the best ways to mitigate students' spelling difficulties is through categorizing the types of their spelling errors and giving instructions and designing plans to solve problems or difficulties related that particular type of errors. It could also be concluded 
that in the present study mirror writing and reverse coding were not deemed as important as the other types of errors among Iranian EFL learners. Overall, the most frequent error types were Visual Memory, Training Error and Listening Accuracy

There is a correlation between English spelling difficulties and linguistic awareness of Iranian EFL students in Malaysia ( $\mathrm{r}=0.763$ ). A significant correlation obtained between the two variables through regression analysis showed that the students' phonological, morphological and orthographical difficulties in spelling are significantly affected by their linguistic awareness. The linguistic awareness can contribute to the teaching and learning spelling particularly among young learners. Learning spelling depends on young learner's acquired knowledge of language, or linguistic awareness; therefore, this knowledge and awareness to the learners is crucial in dealing with spelling difficulties. Another interpretation is that children's developing awareness of linguistic features would generally help them become more proficient language learners. As supported by Masny (1997). As supported by Cook (2010), the finding that EFL learners' phonological (letter-sound) route has a dominant link to their L1 has important implications. This indicates the significance of learners' phonological awareness in L1, as this awareness might affect their spelling learning process in L2. This implication could be significant when giving spelling instructions, given the importance of phones. The teacher's emphasis on the phonetic nature of spelling could play an important role in giving spelling instructions, probably because the written form of English is formed on a phonemic alphabet system. This complicated yet measurable system could be simplified in learning by teachers' highlighting the phonemic nature of spelling and consequently mitigating the young EFL learners' spelling ability. It can be concluded that phonological awareness is vital for adopting the alphabetic rules of a language (i.e., how letters correspond or do not correspond to the speech sounds in a word. The findings of the current study about linguistic awareness could contribute to facilitation of the procedures as well as a richer knowledge of language awareness in learning and teaching language skills, especially spelling skill. Another educational implication of the linguistic awareness, as supported by Hawkins (1999), is the need for students and teachers to participate in overt speculation and expression on language in teaching and learning any mother tongue. Such overt speculation could be enhanced through reflections on the spelling of the words to raise linguistic awareness which could eventually help to mitigate spelling difficulties. In this regard, educators need to be competent in spelling, well-versed with metalinguistic knowledge to describe and explain procedures in spelling, such as asking students about a particular form of spelling associated with examples which already have the form and have the expertise to teach spelling of and in the language (Wright et al., 1993; Putman, 2017).

Another strategy when teaching the rules of spelling could be giving both oral and written instructions. Learners could be asked to search and discover the letter patterns in different words. Therefore, inspiring children to think about their use of spelling strategies could be very useful, especially in terms of building progressive knowledge of English orthography by providing helpful scaffolding for EFL learners.

Since Persian and English languages are typologically different and use different phonetic system, the Persian learners might spell out the words the way those words sound or are pronounced. Some Persian learners are used to transcribing the speech sounds in Persian alphabets which could be a hindrance for learning the correct spelling. This needs to be further investigated in the future studies. Last but not least, interest and curiosity about the words spelling and how those words are governed by certain generalizable rules could be effective in mitigating spelling difficulties among EFL learners. Even though difficulty in understanding English language could make learning the language fearsome (Mullock, 2012), the consistencies, regularities and patterns can offer some scaffolding and systematicity to the learning experience of the learners and facilitate the learning experience for the EFL students. 


\section{REFERENCES}

Abdolrezapour P and Eslami-Rasekh A (2010) A cross-cultural study of perception of politeness by Iranian and American in request forms. Pakistan Journal of Social Sciences, 7(2), 164-169. http://docsdrive.com/pdfs/medwelljournals/pjssci/2010/164-169.pdf

Al-zuoud K M and Kabilan M K (2013) Investigating Jordanian EFL Students' Spelling Errors at Tertiary Level. $\begin{array}{lllll}\text { International of Journal } & \text { Linguistics } & \text { (IJL), } & 5(3), & 164-176 .\end{array}$ https://pdfs.semanticscholar.org/2da7/a3f50d45ce8fb515f90647f6b31a38386378.pdf

Arab-Moghaddam N and Senechal M (2001) Orthographic and phonological processing skills in reading and spelling in Persian/English bilinguals. International Journal of Behavioral Development, 25(2), 140-147. https://journals.sagepub.com/doi/10.1080/01650250042000320

Aronoff $\mathrm{M}$ and Fudeman K (2011) What is morphology?. 3-21, Oxford: Blachwell Publishers. http://www.ucd.ie/artspgs/introling/Aronoffmorphology.pdf

Baleghizadeh S and Dargahi Z (2011) The Use of Different Spelling Strategies among EFL Young Learners. Porta $\begin{array}{lll}\text { Linguarum, } & 15(2), & 151-159 .\end{array}$ https://pdfs.semanticscholar.org/e265/f15ed4100db18d6f206772bca10cc5e6b0dc.pdf

Baluch B (1992) Reading with and without vowels: What are the psychological consequences? Journal of Social and Evolutionary $\quad$ Systems, $15(1), \quad 95-104$. https://www.sciencedirect.com/science/article/abs/pii/106173619290039G

Baluch B (2005) Persian orthography and its relation to literacy. In R. M. Joshi \& P. G. Aaron (Eds.). Handbook of orthography and literacy, 365-376. https://core.ac.uk/download/pdf/19206056.pdf

Bernhardt B M, Kemp N and Werker J F (2007) Early word-object associations and later language development. First Language, 27(4), 315-328. https://journals.sagepub.com/doi/abs/10.1177/0142723707081652

Bird J, Bishop D and Freeman N (1995) Phonological awareness and literacy development in children with expressive phonological impairments. Journal of Speech, Language, and Hearing Research, 38(2), 446462. https://pubs.asha.org/doi/10.1044/jshr.3802.446

Bowers P N, Kirby J R and Deacon S H (2010) The effects of morphological instruction on literacy skills: A systematic review of the literature. Review of Educational Research, 80(2), 144-179. https://journals.sagepub.com/doi/abs/10.3102/0034654309359353?journalCode=rera

Brown H D (2000) Principles of Language Learning and Teaching. White Plains, New York, Longman. https://www.worldcat.org/title/principles-of-language-learning-and-teaching/oclc/42842469

Chandler J (2003) The efficacy of various kinds of error feedback for improvement in the accuracy and fluency of L2 student writing. Journal of Second Language Writing, 12(3), 267-296. https://www.semanticscholar.org/paper/The-efficacy-of-various-kinds-of-error-feedback-forChandler/f999cee760d25977da27e8ebb73ea6a8f732230b

Chenoweth N A and Hayes J R (2001) Fluency in Writing Generating Text in L1 and L2. Written communication, 18(1), 80-98. https://journals.sagepub.com/doi/abs/10.1177/0741088301018001004

Cook, V. J. 2010. L2 users and English spelling. Journal of Multilingual and Multicultural Development, 18(6), 474-488. https://www.tandfonline.com/doi/abs/10.1080/01434639708666335

Deacon S H, Kirby J R and Casselman-Bell M (2009) How robust is the contribution of morphological awareness to general spelling outcomes? Reading Psychology, 30(4), 301-318. https://www.tandfonline.com/doi/abs/10.1080/02702710802412057

Ediger A (2001) Teaching children literacy skills in a second language. In M. Celce-Murcia (Ed.), Teaching English as a second or foreign language, 153-169. Boston, MA: Heinle and Heinle. https://www.academia.edu/36244291/Celce-Murcia_ed Teaching English as a Second_or_Foreign_Language.pdf

Escudero P, Simon E and Mulak K E (2014) Learning words in a new language: Orthography doesn't always help. Bilingualism: language and cognition, 384-395. https://www.cambridge.org/core/journals/bilingualism-language-and-cognition/article/learning-wordsin-a-new-language-orthography-doesnt-always-help/802FD968A3BF270824F92CAABF384913

Gentry J R (1982) An Analysis of Developmental Spelling in" GNYS AT WRK". The reading teacher, 36(2), 192-200. https://psycnet.apa.org/record/1983-07653-001

Georgi R, Xia F and Lewis W (2010) Comparing language similarity across genetic and typologically-based groupings. Proceedings of the 23rd International Conference on Computational Linguistics. Association for Computational Linguistics, 385-393. https://www.aclweb.org/anthology/C10-1044

Ghomeshi J (2003) Plural marking, indefiniteness, and the noun phrase. Studia Linguistica, 57(2), 47-74. https://onlinelibrary.wiley.com/doi/abs/10.1111/1467-9582.00099

Goldwater M B and Gentner D (2015) On the acquisition of abstract knowledge: Structural alignment and explication in learning causal system categories. Cognition, 137(3), 137-153. http://groups.psych.northwestern.edu/gentner/papers/goldwater\%26Gentner_2015.pdf 
Hall M (2007) Phonological characteristics of Farsi speakers of English and 11 Australian English speakers' perceptions of proficiency. Unpublished MA thesis. University of Curtin, Croatia. http://asian-efljournal.com/Thesis-M-Hall.pdf

Halliday M A K, Matthiessen C and Halliday M (2014) An introduction to functional grammar. London: Routledge.

https://www.scirp.org/(S(351jmbntvnsjtlaadkposzje))/reference/ReferencesPapers.aspx?ReferenceID=1 $\underline{304701}$

Hawkins E W (1999) Foreign language study and language awareness. Language Awareness, 8(3-4), 124-142. http://jaling.ecml.at/pdfdocs/hawkins.pdf

Kahn-Horwitz J, Sparks R L and Goldstein Z (2012) English as a foreign language spelling development: A $\begin{array}{lllll}\text { longitudinal study. } & \text { Applied } & \text { Psycholinguistics, } & 33(2), & 363 .\end{array}$ https://www.cambridge.org/core/journals/applied-psycholinguistics/article/english-as-a-foreignlanguage-spelling-development-a-longitudinal-study/15A199C411FBADF17878711DA6E1C9CF

Kalanzadeh G-A, Gohar M J and Bakhtiarvand M (2012) The Influence of Using Word forks on Developing Collocative Competence of Intermediate Iranian EFL Learners. World Journal of English Language, 2(4), 24-28. http://www.sciedupress.com/journal/index.php/wjel/article/view/1682

Karimi S, Turpin A and Scholer F (2006) English to persian transliteration. In Crestani, F. Ferragina P And Sanderson M (Eds.), String Processing and Information Retrieval, 255-266. Australia: Melbourne. https://link.springer.com/chapter/10.1007/11880561 21

Keshavarz M H and Ingram D (2002) The early phonological development of a Farsi-English bilingual child. $\begin{array}{lllll}\text { International of Journal } & \text { Bilingualism, } & 6(3), & \text { 255-269. }\end{array}$ http://citeseerx.ist.psu.edu/viewdoc/download?doi=10.1.1.829.257\&rep=rep1\&type=pdf

Khairunnadiah M S, \& Krish P (2018) English Orthographic Depth among Malay Learners 3L: The Southeast Asian Journal of English Language Studies, 24(1),56-68. http://ejournals.ukm.my/31/article/view/23108

Leong C K, Tan L H, Cheng P W and Hau K T (2005) Learning to read and spell English words by Chinese students. Scientific Studies of Reading, 9(1), 63-84. https://psycnet.apa.org/record/2005-01699-005

Masny D (1997) Linguistic awareness and writing: Exploring the relationship with language awareness. Language Awareness, 6(2-3), 105-118. https://www.tandfonline.com/doi/abs/10.1080/09658416.1997.9959921

Mirhassani A (2003) Theories, approaches and methods in teaching English as a foreign language. Tehran: Zabankadeh Publications. http://ensani.ir/file/download/article/20101209145240-561.pdf

Moghaddam F F (2011) The Relationship between Spelling and Fluency in EFL Writings: A study based on the AIMS six trait analytic writing rubric-official scoring guide. The Iranian EFL Journal, 7(4), 60-71. https://s3.amazonaws.com/academia.edu.documents/8111549/1023483.pdf?response-contentdisposition=inline $\% 3 \mathrm{~B} \% 20$ filename $\% 3 \mathrm{DGenre-based}$ Analysis_of English_Patient.pdf\&X-AmzAlgorithm=AWS4-HMAC-SHA256\&X-AmzCredential=AKIAIWOWYYGZ2Y53UL3A\%2F20190728\%2Fus-east-1\%2Fs3\%2Faws4 request\&X$\underline{\text { Amz-Date }=20190728 T 114359 Z \& X-A m z-E x p i r e s=3600 \& X-A m z-S i g n e d H e a d e r s=h o s t \& X}-A m z-$ $\underline{\text { Signature }=0 b 7937802420 b 0 f 566 b 5 b d 2 a b c 3748 e 58447095 e 80906 d 02 b 013 e b 73 c 7 d 500 a 1 \# \text { page }=60}$

Mullock B (2012) An examination of commercial spelling programs for upper primary level students. Australasian Journal of Special Education, 36(2), 172-195. https://www.cambridge.org/core/journals/australasianjournal-of-special-education/article/an-examination-of-commercial-spelling-programs-for-upperprimary-level-students/68D8A97A55028A0997A39B3866CAC293

Murphy S (2005) Second language transfer during third language acquisition. Teachers College, Columbia University Working Papers in TESOL \& Applied Linguistics, 3(1), 1-21. https://academiccommons.columbia.edu/doi/10.7916/D8SF2VN8

Nunes T, Bryant P and Bindman M (1997) Morphological spelling strategies: developmental stages and processes. Developmental psychology, 33(4), 637-649. https://psycnet.apa.org/record/1997-05230-007

Nunes T, Bryant P and Bindman M (2006) The effects of learning to spell on children's awareness of morphology. Reading and writing, 19(7), 767-787. https://link.springer.com/article/10.1007/s11145-006-9025-y

Pandarangga S (2016) The Transformation Of English As A Global Language In The Future. Lingua, 10(2), 9096.

Peregoy S F, Boyle O F and Phillabaum S (2016) Reading, writing, and learning in ESL: A resource book for K12 teachers. Issues in Applied Linguistics, 20(1), 135-136. https://escholarship.org/uc/item/6gt7j5nf

Putman R (2017) Using Research to Make Informed Decisions about the Spelling Curriculum. Texas Journal of Literacy Education, 5(1), 24-32. https://files.eric.ed.gov/fulltext/EJ1147675.pdf

QasemiZadeh B and Rahimi S (2006) Persian in MULTEXT-East framework. In Advances in Natural Language Processing, $\quad$ Vol, 4139 of $\quad$ LNCS, $451-551 . \quad$ Springer. https://link.springer.com/chapter/10.1007/11816508 54 
Quirk R (1987) A comprehensive grammar of the English language. New York: Pearson Education India. https://journals.sagepub.com/doi/abs/10.1177/007542428702000108

Rahbari N (2019) Error patterns in word reading and spelling in Persian: Is spelling more difficult than reading? Reading and writing, 32(30), 585-601. https://eric.ed.gov/?id=EJ1208089

Roncoli S and Masterson J (2016) 'Unexpected'spelling difficulty in a 10-year-old child with good reading skills: An intervention case study. Writing Systems Research, 8(2), 143-166. https://www.tandfonline.com/doi/full/10.1080/17586801.2016.1159539

Saville-Troike M (2012) Introducing second language acquisition. New York: Cambridge University Press. https://www.cambridge.org/core/books/introducing-second-languageacquisition/1EBA74AF62F480289F7AFAED6F1E71ED

Sénéchal M, Basque M T and Leclaire T (2006) Morphological knowledge as revealed in children's spelling accuracy and reports of spelling strategies. Journal of experimental child psychology, 95(4), 231-254. https://psycnet.apa.org/record/2006-20806-001

Senowarsito and Nur Ardini S (2019) Phonological Fossilisation of EFL Learners: The Interference of Phonological and Orthographic System of L1 Javanese, 3L: The Southeast Asian Journal of English Language Studies, 25(2), 74-85. http:/ejournals.ukm.my/31/article/view/26065/9451

Siegler R S and Crowley K (1991) The microgenetic method: A direct means for studying cognitive development. American Psychologist, 46(6), 606-620. https://psycnet.apa.org/record/1991-27055-001

Solati A (2013) Identify Persian Learners' Linguistic Deficits in Learning EFL through Spelling Error Analysis. Frontiers of Language and Teaching, 4(2013), 196-206. https://www.academia.edu/4140348/Identify Persian Learners Linguistic Deficits in Learning EFL through Spelling Error Analysis

Solati A, Sazalie A and Leh S C (2011) Patterns of Spelling Errors in Language Learners' Language: An Investigation on Persian Learners of English. English and Asia, Universiti Sains Malaysia (USM). http://citeseerx.ist.psu.edu/viewdoc/download?doi=10.1.1.463.721\&rep=rep1\&type=pdf

Souzandehfar M (2011) How to Improve Pronunciation? An In-depth Contrastive Investigation of Sound-spelling Systems in English and Persian. Journal of Language Teaching and Research, 2(5), 1086-1098. http://www.academypublication.com/issues/past/jltr/vol02/05/18.pdf

Tabrizi M, Tabrizi N and Tabrizi A (2013) Disability of Dictation Diagnosis \& Treatment. Tehran: Fararavan Publishing.

Toosarvandani M D (2004) Vowel length in modern Farsi. Journal of the Royal Asiatic Society, 14(3), $241-251$. https:/www.cambridge.org/core/journals/journal-of-the-royal-asiatic-society/article/vowel-length-inmodern-farsi/562BB0F066D50B10446CE8CC4C233CD7

Trask R L (2007) Language and linguistics: the key concepts. London: Routledge. https://catalogue.nla.gov.au/Record/4083867

Ushioda E (2007) Motivation, autonomy and sociocultural theory. In Benson, P. (Ed.), Learner autonomy 8: Insider perspectives on autonomy in language teaching and learning 5-24. Dublin: Authentik. https://www.cambridge.org/core/journals/language-teaching/article/autonomy-in-language-teachingand-learning/7DF3513C76731315FB79C81272553A1F

Verhoeven L (2000) Components in early second language reading and spelling. Scientific Studies of Reading, 4(4), 313-330. https://www.tandfonline.com/doi/abs/10.1207/S1532799XSSR0404 4

Windfuhr G L (2011) Persian grammar: History and state of its study. Berlin: Walter de Gruyter. https://books.google.com.my/books?hl=en\&lr=\&id=uVIEGjCL33wC\&oi=fnd\&pg=PA1\&dq=Windfuhr $+\mathrm{G}+\mathrm{L}+(1979)+$ Persian+grammar:+History+and+state+of+its+study.+Berlin:+Walter+de+Gruyter.\&ots =VKuOf2tgzu\&sig=O_HXS82ZwfemQh76XGbqh5Vvsp4\#v=onepage\&q\&f=false

Wright T and Bolitho R (1993) Language awareness: a missing link in language teacher education? ELT journal, 47(4), 292-304. https://eric.ed.gov/?id=EJ474535

Yavas M and Barlow J A (2006) Acquisition of C clusters in Spanish-English bilingual children. Journal of $\begin{array}{llll}\text { Multilingual Communication } & \text { Disorders, } & 4(3), & 182-193 .\end{array}$ https://www.tandfonline.com/doi/abs/10.1080/14769670601110499 
3L: The Southeast Asian Journal of English Language Studies - Vol 26(4): 157 - 174 http://doi.org/10.17576/3L-2020-2604-12

\section{APPENDIX}

\section{LIST OF WORDS USED IN PRE-TEST AND POST-TEST}

\begin{tabular}{|c|c|}
\hline No. & Word(s) \\
\hline 1 & School \\
\hline 2 & Name \\
\hline 3 & Please \\
\hline 4 & Tell \\
\hline 5 & Teacher \\
\hline 6 & Good afternoon \\
\hline 7 & First \\
\hline 8 & Spell \\
\hline 9 & Below \\
\hline 10 & Table \\
\hline 11 & Classmate \\
\hline 12 & Nice to meet you \\
\hline 13 & Friend \\
\hline 14 & Woman \\
\hline 15 & Sure \\
\hline 16 & Sorry \\
\hline 17 & Again \\
\hline 18 & Birthday \\
\hline 19 & Really \\
\hline 20 & Thirteen \\
\hline 21 & Number \\
\hline 22 & Picture \\
\hline 23 & Mechanic \\
\hline 24 & Housewife \\
\hline 25 & Uncle \\
\hline 26 & Aunt \\
\hline 27 & Nurse \\
\hline 28 & Black \\
\hline 29 & Brown \\
\hline 30 & Excuse \\
\hline 31 & Height \\
\hline 32 & Answer \\
\hline 33 & Kitchen \\
\hline 34 & Cooking \\
\hline 35 & Correct \\
\hline 36 & Phone \\
\hline 37 & Enough \\
\hline 38 & Favorite \\
\hline 39 & Juice \\
\hline 40 & Thirsty \\
\hline
\end{tabular}

